\title{
ReSEARChArticle
}

\section{Efficacy of Pseudomonas fluorescens and Trichoderma viride based bioformulation for management of bacterial wilt disease of ginger}

\author{
POPY BORA, L.C. BORA, P.C. DEKA, BIKRAM BORKOTOKI, A.K. SHARMA, H.S. DUTTA \\ AND DEBAHAJ BUHAGOHAIN
}

\begin{abstract}
SUMMARY
An experiment was conducted to evaluate the efficacy of a consortia formulation of Pseudomonas fluorescens and Trichoderma harzianum for management of bacterial wilt disease of ginger in Assam. Inhibitory effect of the biocontrol agents was evaluated in vitro following dual culture assay method for their efficacy against Ralstonia solanacearum, the ginger wilt pathogen. Quantitative assay of population dynamics of the two antagonists, mass cultured in organic substrates viz., vermicompost (VC) and mustard oil cake (MOC) revealed that the antagonists maintained a high population count up to 120 days of storage at room temperature. Pseudomonas fluorescens recorded highest average population ( $45.47 \times 10^{7} \mathrm{cfu} / \mathrm{g}$ ) when mass cultured in the mixture of VC and MOC, while T. harzianum recorded maximum average population $\left(34.14 \times 10^{7} \mathrm{cfu} / \mathrm{g}\right.$ ) when mass cultured in MOC. Bioformulations were further evaluated for their efficacy in ginger wilt management under field condition. Efficacy of one fungicide (Copper oxychloride) and an antibiotic (Streptocycline) was also tested for comparison. Lowest disease incidence (15.63\%) was recorded in the treatment of seed treatment (ST) and soil application (SA) of $P$. fluorescens and $T$. harzianum consortia mass cultured in the mixture of VC and MOC. It was followed by ST and SA of T. harzianum mass cultured in MOC (21.88\%), which was statistically at par with the application of copper oxychloride (26.25\%).
\end{abstract}

Key Words : Antagonists, Bacterial wilt, Biological management, Ginger, Substrates

How to cite this article : Bora, Popy, Bora, L.C., Deka, P.C., Borkotoki, Bikram, Sharma, A.K., Dutta, H.S. and Buhagohain, Debahaj (2016). Efficacy of Pseudomonas fluorescens and Trichoderma viride based bioformulation for management of bacterial wilt disease of ginger. Internat. J. Plant Sci., 11 (2): 180-186, DOI: 10.15740/HAS/IJPS/11.2/180-186.

Article chronicle : Received : 31.03.2016; Revised : 06.04.2016; Accepted : 20.05.2016

\section{MEMBERS OF THE RESEARCH FORUM}

Author to be contacted :

POPY BORA, Krishi Vigyan Kendra, SONITPUR (ASSAM) INDIA

Email: popy_aau@yahoo.com; pbora.sonitpur10@gmail.com

Address of the Co-authors:

L.C. BORA, Department of Plant Pathology, Assam Agricultural University, JORHAT (ASSAM) INDIA
$---------$

P.C. DEKA, A.K. SHARMA, H.S. DUTTA AND DEBAHAJ BUHAGOHAIN, Krishi Vigyan Kendra, SONITPUR (ASSAM) INDIA

BIKRAM BORKOTOKI, Regional Research Station (A.A.U.), NORTH LAKHIMPUR (ASSAM) INDIA 